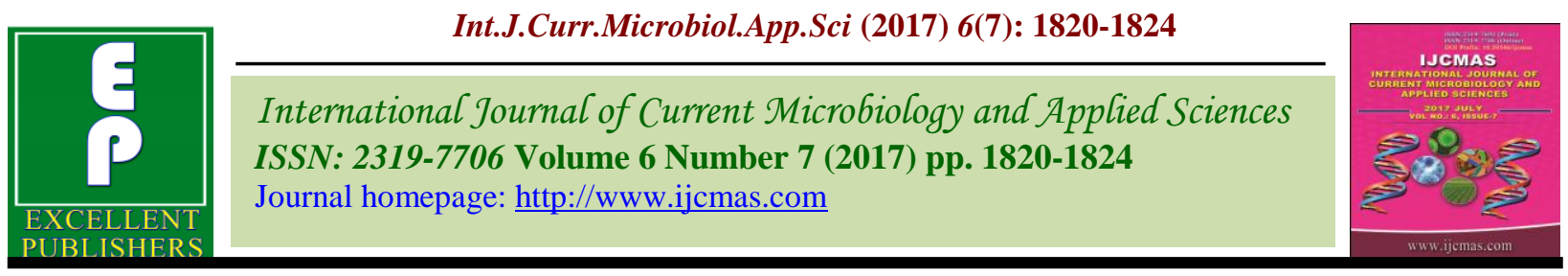

Original Research Article

https://doi.org/10.20546/ijcmas.2017.607.219

\title{
Impact of Crop Establishment, Weed and Nutrient Management Practices on Microbial Population and Grain Yield of Transplanted Rice
}

\author{
V.Sridevi ${ }^{1}$, S. Jeyaraman ${ }^{2}$, S. Ramasamy ${ }^{2}$ and C. Chinnusamy ${ }^{2}$ \\ ${ }^{1}$ Department of Agronomy, Pandit Jawaharlal Nehru College of Agriculture and Research \\ Institute, Karaikal - 609 603, India \\ ${ }^{2}$ Tamil Nadu Agricultural University, Coimbatore, Tamil Nadu, India - 641003 \\ *Corresponding author
}

\begin{abstract}
A B S T R A C T
The field experiments were carried out in clay loam soil of wetland farms of Tamil Nadu Agricultural University, Coimbatore during Samba 2009 and 2010 to elucidate the effect

Keywords

Transplanted rice,

SRI,

Microbial

population

and grain

yield.

Article Info

Accepted:

19 June 2017

Available Online:

10 July 2017

of rice establishment, weed and nutrient management practices on microbial population in the rhizosphere and yield of transplanted rice. The experiments were laid out in split plot design with rice establishment and weed management methods $\left(\mathrm{M}_{1}\right.$ : Conventional planting + hand weeding, $\mathrm{M}_{2}$ : Conventional planting + one way rotary weeding, $\mathrm{M}_{3}$ : SRI planting + hand weeding, $\mathrm{M}_{4}$ : SRI planting + two way rotary weeding) in main plots and nutrient management practices $\left[\mathrm{S}_{1}\right.$ : Absolute control, $\mathrm{S}_{2}: 150: 50: 50 \mathrm{~kg} \mathrm{NPK} \mathrm{ha}{ }^{-1}, \mathrm{~S}_{3}: \mathrm{S}_{2}+12.5 \mathrm{t}$ FYM ha ${ }^{-1}, \mathrm{~S}_{4}: \mathrm{S}_{3}+$ Azophosmet (Seed treatment @ $2 \mathrm{~g} \mathrm{~kg}^{-1}$ and soil application @ $2 \mathrm{~kg} \mathrm{ha}^{-1}$ ) + pink pigmented facultative methylotroph (PPFM) (foliar spray @ $0.1 \%$ at active tillering, panicle initiation and at 50 per cent flowering stage)] in sub plots, replicated thrice. The SRI planting with two way rotary weeding thrice at weekly interval starting from 15 days after transplanting registered higher microbial population in the rhizosphere viz., bacteria, fungi, actinomycetes, Azospirillum, phosphobacteria and Pink pigmented facultative methylotroph (PPFM) at flowering stage and higher grain and straw yield. Microbial population and yield were higher with combined application of recommended dose of fertilizer (150:50:50 kg NPK ha-1) along with 12.5 $\mathrm{t} \mathrm{ha}^{-1}$ FYM and biofertilizers viz., Azophosmet as soil and seed treatment and PPFM as foliar spray.
\end{abstract}

\section{Introduction}

Use of high energy agricultural inputs like fertilizers and pesticides cause environmental hazards, so it is desirable to develop a sustainable production system that give optimum productivity with minimum environmental pollution (Singh et al., 2010). The System of Rice Intensification (SRI) is an alternative for conventional rice cultivation that saves the expensive external inputs, improves soil health/quality and protects the environment substantially (Ram et al., 2014).
Microbes harbouring rhizosphere of crops provide benefits to crops through better nutrient availability by way of atmospheric $\mathrm{N}_{2}$ fixation or solubilizing fixed mineral forms of nutrients (Pandey et al., 2010). Use of integrated nutrient management yields maximum counts and establishment of microbes in soil rather than sole application of chemical fertilizer treatments (Kumar et al., 2014). Keeping foresaid points in view, the field experiments with different crop 
establishment, weed and nutrient management methods were conducted in clay loam soil of Tamil Nadu Agricultural University, Coimbatore during rabi, 2009 and 2010 to assess their effects on the microbial population and yield of transplanted lowland rice.

\section{Materials and Methods}

The field experiments were conducted in clay loam soil of wetland farms, Department of Farm management, Tamil Nadu Agricultural University, Coimbatore during rabi 2009 and 2010 with the medium duration rice variety $\mathrm{CO}(\mathrm{R})$ 50. Field experiments were laid out in split plot design with rice establishment and weed management methods $\left(\mathrm{M}_{1}\right.$ : Conventional planting + hand weeding, $\mathrm{M}_{2}$ : Conventional planting + one way rotary weeding, $\mathrm{M}_{3}$ : SRI planting + hand weeding, $\mathrm{M}_{4}$ : SRI planting + two way rotary weeding) in main plots and nutrient management practices $\left[\mathrm{S}_{1}\right.$ : Absolute control, $\mathrm{S}_{2}: 150: 50: 50$ kg NPK ha ${ }^{-1}, \mathrm{~S}_{3}: \mathrm{S}_{2}+12.5$ t FYM ha $^{-1}, \mathrm{~S}_{4}: \mathrm{S}_{3}$ + Azophosmet (Seed treatment @ $2 \mathrm{~g} \mathrm{~kg}^{-1}$ and soil application @ $\left.2 \mathrm{~kg} \mathrm{ha}^{-1}\right)+$ pink pigmented facultative methylotroph (PPFM) (foliar spray @ $0.1 \%$ at active tillering, panicle initiation and at 50 per cent flowering stage)] in sub plots, replicated thrice. The soil samples collected from rhizosphere of rice at flowering stage were analyzed for microbial population by adopting standard methods. The grain yield was adjusted to 14 per cent moisture content. Data were subjected to an analysis of variance (F-test) as per the methods suggested by Gomez and Gomez (2010).

\section{Results and Discussion}

\section{Microbial population}

The crop establishment and weed management methods have significant influence on the microbial population in the rhizosphere.

The SRI planting with two way rotary weeding thrice at weekly interval starting from 15 days after transplanting during both the years registered higher microbial population in the rhizosphere viz., bacteria, fungi, actinomycetes, Azospirillum, phosphobacteria and Pink pigmented facultative methylotroph (PPFM) at flowering stage could be attributed to larger root volume along with favourable soil condition facilitated by the rotary weeding.

This is in corroboration with the findings of Kumar et al., (2007) who have stated that larger canopies and root systems of SRI plants release more carbohydrates and amino acids into the soil as root exudates, enriching the rhizosphere and supporting greater microbial biomass and diversity.

The microbial population was significantly altered by the nutrient management practices. Population of bacteria, fungi, actinomycetes, Azospirillum, phosphobacteria and PPFM were higher with combined application of recommended dose of fertilizer (150:50:50 kg NPK ha ${ }^{-1}$ ) along with $12.5 \mathrm{t} \mathrm{ha}^{-1}$ FYM and biofertilizers viz., Azophosmet as soil and seed treatment and PPFM as foliar spray might be attributable to higher organic carbon content and external application of biofertilizers.

This finding is in line with the reports of Marschner et al., (2003) who reported that organic and inorganic fertilizers affect the population, composition and function of soil micro organisms. In addition to that, according to Zhao et al., (2010), close relations between microorganism growth and activity to organic matter content in the soil as this provided carbon and energy sources for the growth of microorganisms (Tables 1 and 2). 
Table.1 Effect of crop establishment and weed management methods and nutrient management practices on microbial population viz., bacteria, fungi and actinomycetes

\begin{tabular}{|c|c|c|c|c|c|c|}
\hline \multirow{3}{*}{ Treatments } & \multicolumn{6}{|c|}{ Colony forming units / gram of soil } \\
\hline & \multicolumn{2}{|c|}{ Bacteria $\times 10^{6}$} & \multicolumn{2}{|c|}{ Fungi $\times 10^{5}$} & \multicolumn{2}{|c|}{ Actinomycetes x 10 ${ }^{3}$} \\
\hline & 2009 & 2010 & 2009 & 2010 & 2009 & 2010 \\
\hline \multicolumn{7}{|c|}{ Crop establishment and weed management methods } \\
\hline $\begin{array}{l}\mathrm{M}_{1} \text { : Conventional planting }+ \text { hand } \\
\text { weeding }\end{array}$ & 21.58 & 21.08 & 5.00 & 4.58 & 6.00 & 5.17 \\
\hline $\begin{array}{l}\mathrm{M}_{2} \text { : Conventional planting + one } \\
\text { way rotary weeding }\end{array}$ & 23.25 & 22.75 & 6.00 & 5.50 & 6.42 & 5.33 \\
\hline $\mathrm{M}_{3}:$ SRI planting + hand weeding & 23.00 & 22.67 & 5.25 & 4.92 & 6.42 & 5.33 \\
\hline $\begin{array}{l}\mathrm{M}_{4}: \text { SRI planting + two way rotary } \\
\text { weeding }\end{array}$ & 24.83 & 24.17 & 6.67 & 6.25 & 7.25 & 6.17 \\
\hline SEd & 0.57 & 0.49 & 0.27 & 0.28 & 0.25 & 0.29 \\
\hline CD at $5 \%$ & 1.40 & 1.20 & 0.66 & 0.69 & 0.62 & 0.71 \\
\hline \multicolumn{7}{|l|}{ Nutrient management practices } \\
\hline $\mathrm{S}_{1}:$ Absolute control & 15.08 & 14.75 & 4.83 & 4.42 & 5.25 & 4.25 \\
\hline $\mathrm{S}_{2}: 150: 50: 50 \mathrm{~kg} \mathrm{NPK} \mathrm{ha}^{-1}$ & 21.67 & 21.17 & 5.17 & 4.83 & 5.92 & 5.08 \\
\hline $\mathrm{S}_{3}: \mathrm{S}_{2}+12.5 \mathrm{t} \mathrm{FYM} \mathrm{ha}^{-1}$ & 26.08 & 25.58 & 6.00 & 5.58 & 7.08 & 6.08 \\
\hline $\mathrm{S}_{4}: \mathrm{S}_{3}+$ Azophosmet $+0.1 \%$ PPFM & 29.83 & 29.17 & 6.92 & 6.42 & 7.83 & 6.58 \\
\hline SEd & 0.52 & 0.51 & 0.18 & 0.18 & 0.19 & 0.17 \\
\hline CD at $5 \%$ & 1.06 & $\mathbf{1 . 0 5}$ & 0.37 & 0.36 & 0.38 & 0.35 \\
\hline
\end{tabular}

Table.2 Effect of crop establishment and weed management methods and nutrient management practices on microbial population viz., Azospirillum, Phosphobacteria and PPFM

\begin{tabular}{|c|c|c|c|c|c|c|}
\hline \multirow{3}{*}{ Treatments } & \multicolumn{6}{|c|}{ Colony forming units / gram of soil } \\
\hline & \multicolumn{2}{|c|}{ Azospirillum $\times 10^{3}$} & \multicolumn{2}{|c|}{ Phosphobacteria $\times \mathbf{1 0}^{3}$} & \multicolumn{2}{|c|}{ PPFM $\times 10^{3}$} \\
\hline & 2009 & 2010 & 2009 & 2010 & 2009 & 2010 \\
\hline \multicolumn{7}{|c|}{ Crop establishment and weed management methods } \\
\hline $\begin{array}{l}\mathrm{M}_{1} \text { : Conventional planting + hand } \\
\text { weeding }\end{array}$ & 7.58 & 7.25 & 17.75 & 16.25 & 5.17 & 5.58 \\
\hline $\begin{array}{l}\mathrm{M}_{2}: \text { Conventional planting + one } \\
\text { way rotary weeding }\end{array}$ & 8.42 & 7.92 & 18.75 & 17.33 & 5.42 & 5.83 \\
\hline $\mathrm{M}_{3}$ : SRI planting + hand weeding & 8.42 & 7.83 & 18.50 & 17.08 & 5.50 & 5.67 \\
\hline $\begin{array}{l}\mathrm{M}_{4} \text { : SRI planting + two way rotary } \\
\text { weeding }\end{array}$ & 9.42 & 8.58 & 20.08 & 18.67 & 6.58 & 6.50 \\
\hline SEd & 0.26 & 0.20 & 0.60 & 0.51 & 0.27 & 0.25 \\
\hline CD at $5 \%$ & 0.64 & 0.49 & 1.47 & 1.24 & 0.67 & 0.61 \\
\hline \multicolumn{7}{|l|}{ Nutrient management practices } \\
\hline $\mathrm{S}_{1}:$ Absolute control & 6.58 & 6.33 & 14.42 & 14.08 & 4.50 & 4.92 \\
\hline $\mathrm{S}_{2}: 150: 50: 50 \mathrm{~kg} \mathrm{NPK} \mathrm{ha}^{-1}$ & 7.75 & 7.25 & 18.75 & 17.00 & 5.17 & 5.50 \\
\hline $\mathrm{S}_{3}: \mathrm{S}_{2}+12.5 \mathrm{t} \mathrm{FYM} \mathrm{ha}^{-1}$ & 9.25 & 8.67 & 19.50 & 17.75 & 5.67 & 6.00 \\
\hline $\mathrm{S}_{4}: \mathrm{S}_{3}+$ Azophosmet $+0.1 \%$ PPFM & 10.25 & 9.33 & 22.42 & 20.50 & 7.33 & 7.17 \\
\hline SEd & 0.22 & 0.17 & 0.51 & 0.32 & 0.25 & 0.17 \\
\hline CD at $5 \%$ & 0.46 & 0.34 & 1.05 & 0.66 & 0.51 & 0.36 \\
\hline
\end{tabular}


Table.3 Effect of crop establishment and weed management methods and nutrient management practices on grain and straw yield of transplanted rice

\begin{tabular}{|c|c|c|c|c|}
\hline \multirow{2}{*}{ Treatments } & \multicolumn{2}{|c|}{ Grain yield $\left(\mathrm{Kg} \mathrm{ha}^{-1}\right)$} & \multicolumn{2}{|c|}{ Straw yield $\left(\mathrm{Kg} \mathrm{ha}^{-1}\right)$} \\
\hline & 2009 & 2010 & 2009 & 2010 \\
\hline $\begin{array}{l}\mathrm{M}_{1} \text { : Conventional planting }+ \text { hand } \\
\text { weeding }\end{array}$ & 5286 & 4912 & 7237 & 6565 \\
\hline $\begin{array}{l}\mathrm{M}_{2} \text { : Conventional planting + one way } \\
\text { rotary weeding }\end{array}$ & 5731 & 5575 & 7608 & 7229 \\
\hline $\mathrm{M}_{3}:$ SRI planting + hand weeding & 5472 & 5170 & 7076 & 6523 \\
\hline $\begin{array}{l}\mathrm{M}_{4}: \text { SRI planting }+ \text { two way rotary } \\
\text { weeding }\end{array}$ & 6107 & 5901 & 7761 & 7526 \\
\hline SEd & 189 & 194 & 281 & 209 \\
\hline CD at $5 \%$ & 461 & 475 & NS & 512 \\
\hline $\mathrm{S}_{1}:$ Absolute control & 4675 & 4379 & 6106 & 5651 \\
\hline $\mathrm{S}_{2}: 150: 50: 50 \mathrm{~kg} \mathrm{NPK} \mathrm{ha}^{-1}$ & 5579 & 5367 & 7718 & 7178 \\
\hline $\mathrm{S}_{3}: \mathrm{S}_{2}+12.5 \mathrm{t} \mathrm{FYM} \mathrm{ha}^{-1}$ & 6052 & 5762 & 7848 & 7503 \\
\hline $\mathrm{S}_{4}: \mathrm{S}_{3}+$ Azophosmet $+0.1 \%$ PPFM & 6288 & 6050 & 8010 & 7510 \\
\hline SEd & 112 & 100 & 170 & 172 \\
\hline CD at $5 \%$ & 231 & 207 & 352 & 354 \\
\hline
\end{tabular}

\section{Yield}

The SRI planting with two way rotary weeding thrice at weekly interval starting from 15 days after transplanting registered significantly higher grain and straw yield during both the years might be attributable to larger root system and crop canopy and higher microbial population which facilitated the enhanced nutrient uptake, photosynthetic activity and remobilization of photosynthates. However, the straw yield was not significantly altered due to the crop establishment and weed management practices during 2009. This is in conformity with the findings of Sridevi and Chellamuthu (2012) and Revathi (2009) (Table 3).

Combined application of recommended dose of fertilizer (150:50:50 kg NPK ha ${ }^{-1}$ ) along with $12.5 \mathrm{t} \mathrm{ha}^{-1}$ FYM and bio fertilizers viz., Azophosmet as soil and seed treatment and PPFM as foliar spray registered higher grain and straw yield might be attributed to greater root development and activity, higher microbial population and increased nutrient availability throughout the crop growth. This finding is in accordance with the findings of Virdia and Mehta (2010) and Sharma et al., (2017)

In conclusion, the results of the present investigation revealed that SRI planting + two way rotary weeding along with recommended dose of fertilizer (150:50:50 kg NPK ha $\left.{ }^{-1}\right)+$ 12.5 t FYM ha ${ }^{-1}+$ Azophosmet (seed and soil application $)+$ PPFM (0.1\% foliar spray) at active tillering, panicle initiation and at 50 per cent flowering stage registered higher microbial population viz., bacteria, fungi, actinomycetes, Azospirillum, phosphobacteria and PPFM in the rhizosphere during flowering stage which in turn resulted in higher grain and straw yield of the medium duration rice variety $\quad \mathrm{CO}(\mathrm{R}) 50$ during rabi in the clay loam soil of Coimbatore.

\section{References}

Gomez, K.A. and Gomez, A.A. 2010. Statistical procedures for agricultural 
research, (2 $2^{\text {nd }}$ Ed.), Wiley India Pvt Ltd., India.

Kumar, A., Kumar, P., Gera, R., Kumar, M. and Ishmadhu. 2014. Effect of integrated nutrient management on crop yield, available nutrient status and microbial status of soil in pearl milletwheat cropping system. Crop Res., 48(1,2\&3): 22-26.

Kumar, R.M., Surekha, K., Padmavathi, Ch., Rao, L.V.S., Babu, V.R., Singh, S.P., Subbaiah, S.V., Muthuraman, P. and B.C. Viraktamath. 2007. Technical bulletin on System of rice intensification - A water saving and productivity enhancing strategy in irrigated rice. Directorate of Rice Research, Hyderabad, India.

Marschner, P., Kandeler, E. and Marschner, B. 2003. Structure and function of the soil microbial community in a long term fertilizer experiment. Soil Biol. Biochem., 35: 453-461.

Pandey, M.P., Verulkar, S.B. and Sharma, D. 2010. Rice research: past achievements, present scenario and future thrust. Indian J. Agric. Sci., 80(6): 447-69.

Ram, H., Singh, J.P., Bohra, J.S., Singh, R.K. and Sutaliya, J.M. 2014. Effect of seedlings age and plant spacing on growth, yield, nutrient uptake and economics of rice (Oryza sativa) genotypes under system of rice intensification. Indian J. Agronomy, 59(2): 256-260.
Revathi, A. 2009. Establishment techniques and weed management practices in puddled lowland rice. M.Sc. (Ag.) Thesis. Tamil Nadu Agricultural University, Coimbatore, Tamil Nadu, India.

Sharma, A., Kachroo, D., Puniya, R., Ram, H., Joshi, D., Soni, P.G., Yadav, T. and Yadav, M.R. 2017. Impact of different transplanting dates and nutrient sources on soil microbial population and grain yield of basmati rice (Oryza sativa L.) grown under SRI. Int. J. Curr. Microbiol. App. Sci., 6(3): 778-782.

Singh, Y.V., Singh, K.K., Sharma, S.K. and Meena, D.S. 2010. Effect of integrated nutrient management on yield and seed quality in rice. Oryza, 47(3): 215-220.

Sridevi, V. and Chellamuthu, V. 2012. Influence of System of Rice Intensification on Growth, Yield and Nutrient Uptake of Rice (Oryza sativa. L). Madras Agric. J., 99(4-6): 305-307.

Virdia, H.M., Mehta, H.D. 2010. Integrated Nutrient Management in transplanted rice (Oryza sativa L.). Int. J. Agric. Sci., 6(1): 295-299.

Zhao, L., Wu, L., Li, Y., Animesh, S., Zhu, D. and Uphoff, N. 2010. Comparisons of yield, water use efficiency and soil microbial biomass as affected by the System of Rice Intensification. Communications in Soil Sci. Plant Analysis, 41: 1-12.

\section{How to cite this article:}

Sridevi, V., S. Jeyaraman, S. Ramasamy and Chinnusamy, C. 2017. Impact of Crop Establishment, Weed and Nutrient Management Practices on Microbial Population and Grain Yield of Transplanted Rice. Int.J.Curr.Microbiol.App.Sci. 6(7): 1820-1824. doi: https://doi.org/10.20546/ijcmas.2017.607.219 